Каневская О. Б. кандидат педагогических наук, доцент

Щербак C. В. кандидат филологических наук, доцент КПИ ГВУЗ «Криворожский национальный университет»

\title{
ОСОБЕННОСТИ НАЦИОНАЛЬНОЙ СПЕЦИФИКИ ИЗОБРАЖЕНИЯ ПЕРСОНАЖЕЙ В РУССКИХ И УКРАИНСКИХ НАРОДНЫХ СКАЗКАХ
}

У статті проаналізовані російські та украӥнські казки з точки зору відображення в них національної специфіки змалювання персонажів.

Ключові слова: народні казки, казковій персонаж, фольклор, національна специцфіка.

В статье проанализированы русские и украинские сказки с точки зрения отражения в них национальной специифики изображения персонажей.

Ключевые слова: народные сказки, сказочный персонаж, фольклор, национальная специифика.

In the article Russian and Ukrainian fairy tales have been analysed from the point of their reflection the national specific in description of heroes.

Key words: folk tales, tale hero, folklore, national specific.

Общеизвестно, что народная сказка как повествовательный фольклорный жанр представляет собой своеобразную концентрацию всего опыта людей, отражающего их мировосприятие, а также 
всего того, что создано веками народом в образной и выразительной живой разговорной речи.

Изучением русских и украинских народных сказок как составляющей духовной культуры народов занимался целый ряд ученых: С. Аверинцев, А. Афанасьев, В. Бойко, Я. Боровский, О. Брицына, П. Гуревич, Л. Дунаевская, 3. Лановык, М. Лановык, А. Лосев, М. Матье, Е. Мелетинский, С. Мокиенко, А. Потебня, В. Пропп, Б. Путилов, О. Фрейденберг и мн. др.

Актуальность данного исследования определяется повышенным интересом фольклористики к изучению проявления национального менталитета в сказках и отражения в них отдельных фрагментов языковой картины мира.

Цель статьи - проанализировать русские и украинские народные сказки с точки зрения отражения в них национальной специфики изображения персонажей.

Сказка - это такое отражение жизни народом в самых различных ее аспектах, в котором синтезируется народной мудрости, народный талант, народное мировоззрение. Поэтому она - явление по-своему историческое. Да и появилась она тогда, когда человек переставал мыслить мифологически, когда чисто поэтический вымысел начал играть преобладающую роль [Рошияну 1974: 37 ].

Украинские ученые-фольклористы уточняют, что украинская сказка - это прежде всего эпическое произведение фантастического, аллегорического и социально-бытового характера, со своеобразной системой художественных приемов, которые служат для героизации позитивных персонажей [Золота книга казок 1990: 5].

Первобытные сказки отражали первобытные обряды и мифологические воззрения. Они могли возникать как отклики на действительные события и передавались как «быль», но сами эти события интерпретировались в рамках господствующих представлений о различных духах, воплощавших силы природы.

Одновременно с процессом углубления познания окружающего мира, мировоззрение сказителя перестает совпадать полностью 
с мифологическими представлениями, которые содержала сказка. А это со временем привело к тому, что сказка стала осознаваться как плод поэтического вымысла. В.Я. Пропп в работе «Морфология сказки» отмечает, что все сказки постепенно изменяются, трансформируются, метаморфизируются. На них оказывают влияние эпос соседних народов, письменность, религия - как христианская, мусульманская, так и местные поверья. Однако, несмотря на неизбежные влияния, сказка продолжает сохранять в своих недрах следы древнейшего язычества, древних обычаев и обрядов [Пропп 1928: 98].

И русские, и украинские народные сказки отличаются друг от друга не только внешними признаками, характером сюжетов, героев, поэтикой, идеологией и т. д., они могут быть различными и по своему происхождению, поэтому подходы, методы и приемы их изучения могут быть разными. Ученые, исследовавшие «судьбы русской сказки» (А. Н. Афанасьев, Э. В. Померанцева, В. Я. Пропп), предлагали различные системы классификации сказок. Например, А. Н. Афанасьев выделяет сказки о животных, волшебные, мифологические, фантастические, былинные, исторические сказания, новеллистические или бытовые, былички, народные анекдоты, докучные, прибаутки [Народные русские сказки 1992]. Украинские фольклористы в сказочном эпосе выделяют культовоанимистические сказки, сказки о животных, волшебные сказки, социально-бытовые сказки [Золота книга казок 1990].

Безусловно, практически во всех сказках, будь то сказки о животных или фантастические сказки, былички или волшебные сказки, ярко отражаются национальная психология, многообразные формы поведения и взаимоотношений людей. Так, в многочисленных в украинском фольклоре сказках о животных («Котик $\mathrm{i}$ півник», «Кіт, цап і баран», «Лисиця та їжак», «Сірко», «Лисичкасестричка і вовк-панібрат», «Три брати і кицька») через взаимоотношения в животном мире выражаются многообразные формы поведения людей, их бытовые и семейные обычаи и нравы, этикоэстетические представления. 
«Русская народная сказка повествует о русском и ключевых понятиях его ментальности. В ее сокровенном смысле находим ответы на вечные вопросы: что такое счастье, что такое судьба, существуют ли в жизни злье силь, куда ведет кривда, и что такое люди», - пишет В. В. Колесов в книге «Русская ментальность в языке и тексте» [Колесов 2006: 213]. По нашему мнению, это утверждение ученого не полностью переложимо на украинские народные сказки, в которых отражаются немного иные представления народа об украинском, иными средствами выражаются украинская ментальность и представления о счастье, о добре и зле, правде и лжи. Таким образом, несмотря на то, что сказки создавались в глубокой древности, они уже тогда содержали ценную информацию о специфике национального менталитета. При этом следует подчеркнуть, что черты, определяющие национальный менталитет, отличаются большой стабильностью. «B историческом развитии некоторые главные особенности характера и склада ума этноса отличаются неизменными, а если и испытывают, то сравнительно незначительные изменения и преобразования», - утверждал Ф. Х. Кессиди [Кессиди 2000: 18]. Более того, менталитет национальной культуры, даже претерпевая некоторые изменения в ходе истории, все же остается в своей основе постоянным, что позволяет идентифицировать культуру на всем ее историческом пути от зарождения до расцвета и, возможно, упадка. «Я убежден, - писал Б. П. Вышеславцев, - что народный характер необычайно устойчив, быть может, он даже всегда остается тем же, и самые неожиданные и невероятные колебания судьбы вскрывают только его скрытые, но всегда присутствовавшие потенции» [Вышеславцев Б. П. Русский национальный характер [Электронный ресурс] http://www.philosophy.ni].

В рамках данного исследования рассмотрим несколько примеров национальной интерпретации наиболее известных сказочных символов и героев. 
Так, галерея героических персонажей украинских народных сказок создана главным образом представителями села: Котигорошко, Чабанець, Іван-Голик, Іван-Вітер, Лугай и др. Невероятная сила героя-богатыря проявляется еще в детстве, он совершает подвиги, освобождая девушку, невесту, жену из плена змея, Кощея и других захватчиков.

В русских народных сказках много положительных персонажей, которые являются носителями этических идеалов русского народа; часто это царевичи и царевны (Иван-царевич, Елена Прекрасная, Василиса Премудрая и т. д.), однако встречаются и простолюдины: Емеля, Иван-дурак, Марья-искусница и др. Их достоинства заключены не во внешних, а во внутренних душевных качествах и проявляются в поступках, взаимоотношениях с людьми и миром в целом. Например, Иван-дурак (синонимы в европейских сказках Джон или Жак Простак) - специфически русский тип, потому что, вероятно, только русский способен смеяться над своими недостатками, не видя в том никакого ущемления своему достоинству. Но русский дурак - вовсе не дурак, он - инверсия мудрецу. Дурак русских сказок обладает нравственными достоинствами, и это важнее наличия внешнего ума, - уточняет В. Я. Пропп [Пропп 1928]. Дурака не прельщают материальные ценности, он несребролюбивый: «"Экая пропасть золота! Куда мне с ним?" - подумал дурак и пошел по городам да по селам оделять нищую братию; раздал два бочонка, а на третий купил ладану... и зажег; воскурялось благоухание и пошло к богу на небеса» («Мудрая жена»). Это подтверждают и его жизненные цели: найти свою судьбу, счастье, невесту, разгадать загадки хитрой царевны, «себя показать, людей посмотреть», «удаль испробовать», «хочу идти туда - сам не знаю куда». Он добряк, альтруист, готов пожертвовать собой ради блага ближнего, готов терпеть все лиха и напасти «через красу». Он честен. Воспользовавшись чудесными дарами, которые ему не принадлежат (шапка-невидимка, ковер-самолет, сапоги-скороходы), дурак всегда возвращает их владельцам (братьям, стариам, чертям). 
Любопытно, что после свадьбы дурак полностью преображается, и никто его уже не называет дурнем: «Дурень нарядился в те дорогие уборы, сделался таким молодцом, что и сказать нельзя! Явился к изарю, обвенчался с изаревною, получил большое приданое и стал разумным и догадливылм» («Летучий корабль»); «...Елена Прекрасная скоро с ним обвенчалась; а он-то, боже мой, какой стал умный да смельй, а какой красавец!..» («Сивкобурка»).

Главные женские образы русских народных сказок - Елена Прекрасная и Василиса Премудрая. Имена этих героинь очень значимы. Обратимся вновь к исследованиям В.В.Колесова. Он пишет: «В древности имя - это сама "вещьь", сам человек в своей сушности. Елена - святая, свет, а свет пре-красен. Василиса царственная, и мудрость - царственна. Можно думать, что Василиса явилась в Древней Руси в связи с поклонением Софии Премудрой Божией, а Елена уже в ХV в., в Московской Руси, с ее поклонением Свету божественной Троищы» [Колесов 2006: 289]. Красота и мудрость представлялись древними славянам настолько возвышенными, что они навеки запечатлелись в сказках.

Светлая, неземная красота девицы вдохновляет молодца на подвиги, дает силы претерпевать все горести. В сказке «Морской царь и Василиса Премудрая» Иван делится своей бедой с Василисой, прислушивается к ее советам, разрешает себя учить. Мудрая сестрица раньше братьев находит диковины, выручает их (братьев) из беды, а они благодарят ее глубоким уважением («Поющее дерево и птица-говорунья»). А в сказке «Василиса Поповна» Василиса Васильевна вообе ведет себя не по-девичьи: одевается в мужское платье, ездит верхом на лошади, стреляет из ружья. Большинство русских волшебных сказок превозносят духовное богатство героинь, их доброту, кротость, смирение, а также услужливость и хозяйственность.

Безусловно, русская семья строилась с учетом христианских норм, оставляющих мужу право главенствовать. Однако, прекло- 
нение пред жизнедающей Матерью-Землей, пред матерью как отголосок языческого культа сохранилось в сознании русских. Поэтому женщина в русской семье чтится как мужем, так и детьми, ее труд, мнение, советы ценятся (см.: «Жена-спорщица», «Как старик домовничал»). Она - источник любви, тепла, мира, она творец и хранитель семейного очага.

Отголоски древних традиционных представлений славян заключены в образах Бабы-яги, Змея Горыныча, Кощея Бессмертного.

Образ Бабы-Яги (Ягишна, яга-бура, бабушка-задворенкаягинишна) как наиболее древний образ русской мифологии из заботливой берегини, прародительницы, древнего положительного божества славянского пантеона, хранительницы рода и традиций был трансформирован в злой фольклорный персонаж. Баба-Яга лесная старуха-волшебница (ведьма), хозяйка зверей и лесного пространства; это старуха, сгорбленная, худая, у нее большой, загнутый вниз, крючковатый нос, костяная нога. Она одета в лохмотья; живет в избушке на курьих ножках; умеет колдовать, владеет тайнами приготовления различных снадобий; летает в ступе, управляет помелом [Кхерибиш М. Лексикографическое описание русских народных сказок в учебных целях: автореф. дис. ... канд. филол. наук [Электронный ресурс] http://www.pushkin.edu.ru/].

Избушка Бабы-Яги всегда стоит к лесу передом, ее нужно повернуть, чтобы герой смог попасть в неё (в иное царство, в иной мир). Двери лесной избушки открываются только после произнесения магических слов: «Избушка, избушка, повернись к нам передом, клесу задом; нам в тебя лезти, хлеба-соли ести». Интересно, что образ Бабы-Яги многозначен. В зависимости от ситуации она бывает и добрая, и злая. Баба-Яга может выступать как воительница, похитительница детей, пожирательница людей («Баба-Яга и жихарь», «Медведко, Усыня, Горыня и Дугиня - богатыри», «Баба-Яга», «Ивашко и ведьма», «Марья Моревна», «Иван-царевич и Белый Полянин», др.). В этих сказках Баба-Яга наказывается смертью или остается ни с чем. А может быть и помощницей положи- 
тельного героя: указывает ему дорогу в царство Кощея, дарит различные волшебные предметы (клубок, гребень, камень и др.), которые помогают герою в пути («Иван Быкович», «Василиса Прекрасная», «Царь-медведь», «Морской царь и Василиса Премудрая», «Царевна-лягушка», «Заколдованная королевна», «По щучьему веленью и т. д.). Всех тех, кто приходит к ней, она обязательно испытывает на чистоту души.

По поводу образов Кощея Бессмертного и Змея Горыныча спорят и сегодня, существует множество гипотез и толкований. Остановимся на самых известных и признанных среди ученых и исследователей.

Кащей / Кощей / Кош - сказочное лицо, вроде вечного жида; вероятно от «кастить», но переделано в «кощей», от «кости», означая изможденного непомерною худобою человека, особенно старика, скрягу, скупца и ростовщика, корпящего над своею казною; «кащейка» - скупая, весьма худая старуха.

Кощея называют Бессмертным, и он на самом деле неуязвим, непобедим, но только для тех, кто не знает тайну его смерти. «Где же у тебя смерть, Кош Бессмертный?» - «У меня смерть в таком-то месте: там стоит дуб, под дубом ящик, в ящике заяи, в зайце утка, в утке яйцо, в яйце смерть моя».

В его огромном дворце томится прекрасная девица. Кощей вихрем унес ее из родных мест, чтобы владеть этой неземной красотой вечно (см.: «Кощей Бессмертный», «Марья Моревна», «Царевна-Лягушка»).

Кощзей, по мнению некоторых ученых, - воспоминания славян о реальных событиях, которые происходили почти 2 тыс. лет назад. В начале II в. н. э. для славян, живущих по Днепру, наступил «золотой век». С кочевниками сарматами был заключен мир, основанный, в частности, на многочисленных смешанных браках. Начал функционировать торговый путь «из варяг в греки». Открылась торговля с Римской империей. Почти 300 лет практически не было войн. Люди строили деревянные дома, выращивали хлеб. 
Существовала настоящая общественная идиллия - простая жизнь среди природы и социальное равенство. Однако в конце II - начале III в. н. э. в Причерноморье появились готы, вестготы и остготы, переселенцы из Скандинавии. Остготы поселились у берегов Азовского моря. В IV веке они часто совершали грабительские морские походы по Черному морю. В первое время нападения были безуспешными, но потом ситуация начала меняться. И на сцене появился Кощей, разрушающий многолетний покой, счастье всю красоту мирной жизни, приносящий лишь ужас и смерть [11].

Змей Горыныч (чудо-юдо) - русский сказочный змей, многоголовый, крылатый, лапчатый, житель горы, пещеры. Своим огненным дыханием он уничтожает крестьянские посевы и даже целые селения и частенько уносит с собой в небеса прекрасных дев (см.: «Иван-царевич» и «Марфа Царевна», «Иван Быкович», «Два Ивана солдатских сына», «Фролка-сидень», «Чудесная рубашка» и др.).

Исследователи считают, что образ Змея Горыныча отражает тему борьбы славян с их лютыми врагами - степными кочевниками татаро-монголами, которые при нападениях использовали китайские огневые снаряды. Эти взрывчатки с прикрепленными к ним украшениями-крыльями и хвостами китайских драконов падали буквально с неба. Из неразорвавшихся шипящих снарядов и гранат с нефтью вытекала черная маслянистая жидкость, которая с трудом впитывалась в землю (ср.: у Змея Горыныча черная кровь). Предполагают, что Змей Горыныч - олицетворение этого оружия, нового, загадочного и страшного для славян, которые столкнулись с ним в период татаро-монгольского нашествия, это метафорический образ артиллерийского обстрела [Китай - родина Змея Горыныча? http:// www.epzodsspace.testpilot.ru/].

В русских народных сказках, по мнению В. Я. Проппа, змей всегда образ многоголовый и не владеет в бою оружием [Пропп 1928]. А в украинских народных сказках - «змій тільки вуса покручує» («Про Сученка-богатиря»), «От у змія меч на три сажені залізний чи стальний, як ударить він чабанця ним, так меч на шматки і 
розкочивсь» («Чабанець»), или «Зміївни хустки гаптують, а стара змія на печі лежить» («Про Сученка-богатиря»), «зміївни відомо посідали втрьох на печі та й радяться, як би царевича звести» («Іван Царевич і залізний вовк»).

Сказки о животных - самые первые и любимые сказки маленьких детей. В украинских народных сказках встречаются такие животные: лисичка-сестричка, вовк-панібрат, вовк-колядун, вовчок-толчок, їжачок, коза-дереза, журавель, солом'яний бичок, кіт, собака, петух и др. В русских сказках о животных - орел, лев, мышь, ворон, конь, коза, козел, заяи, волк, петух, курица, пчелка, лиса, медведь, свинья, бычок, белка, дрозд, тетерев, баран, кот, кошка, слепень, собака, дятел, щука, муха, вошь, блоха, комар, ящерка, рак, сокол, журавль, цапля.

Однако чаще всего как в русских, так и в украинских сказках действуют такие персонажи (зоосимволы): лиса (лисичка-сестричка, Лисафья Кума, Лиса Патрикиевна, Лизавета Ивановна), волк (Волчик, Серый Волчок, Левон Иваныч), медведь (косолапый Мишка, Михайло Иваныч, Михайло Потапыч), кот (кот Васька, Кот Котонаевич, Котофей Иванович, котишко-мурлышко серый любишко), петух (Петя-петушок), собака (пестрый кобель), заяч (косой черт, косой пострел) и др. Многие из этих зоосимволов наделены определенными качествами и выражают определенную оценочность. Например, «Лиса» всегда сопровождается отрицательной коннотацией. От других животных ее отличает хитрость, жадность, расчетливость, агрессивность, жестокость, кровожадность. В очень редких случаях она играет роль помощника, но обязательно с выгодой для себя. «Петух» является защитником людей от нечистой силы; также он символизирует задиристость и драчливость [Чай Кен Нам http://www. ruslang.ru/]. «Собака» является, с одной стороны, символом надежной защиты, преданности и верности, а с другой, - символом физической и моральной грязи. «Вол»- олицетворение силы выносливости, трудолюбия. У «коня» во всех сказках только положительные эпитеты - прилагательные 
с положительной коннотацией (добрый, чудеснылй, богатырский, любезный, чудныци, ретивыци, славный, борзыц̆, быстрый, верный, волшебный). Волшебный конь обладает чудесными свойствами: говорит, ест жар, из ноздрей его пышет пламя и т. д. Этому дивному коню приданы все свойства грозовой тучи: бурый цвет, необычайная скорость, полет по поднебесью, выдыхание жгучего пламени и т. д. [Рошияну 1974: 101-102]. Следует отметить, что некоторые исследователи, работающие с необработанными вариантами сказок, разгадывают первоначальные смыслы сказочных символов. Например, Петушок - золотой гребешок на самом деле образ солнышка, которое ночь - Лиса - уносит «за высокие горы, за дремучие леса, за синие моря» [Маремишова И. Русские сказки [Электронный ресурс] http://www.rustrana.ru/].

Итак, проанализированный нами материал подтверждает, что ментально-культурологическое богатство русских и украинских народных сказок неисчерпаемо.

\section{БИБЛИОГРАФИЯ}

Вышеславцев - Вышеславцев Б. П. Русский национальный характер [Электронный ресурс] / Б. П. Вышеславцев. - Режим доступа: http: //www.philosophy.ni/. Золота книга казок 1990 - Золота книга казок: українські народні казки. - К. : Веселка, 1990. $-431 \mathrm{c}$.

Кессиди 2000 - Кессиди Ф. Х. О парадоксе России / Ф. Х. Кессиди // Вопросы философии. - 2000. - № 6. - С. 18-20.

Китай - родина Змея Горыныча? [Электронный ресурс]. - Режим доступа: http:// www.epzodsspace.testpilot.ru/.

Колесов 2006 - Колесов В. В. Русская ментальность в языке и тексте / В. В. Колесов. - СПб. : Петербургское востоковедение, 2006. -624 с.

Кхерибиш М. Лексикографическое описание русских народных сказок в учебных целях : автореф. дис. ... канд. филол. наук : 10.02 .01 - русский язык [Электронный peсурс] / М. Кхерибиш. - Режим доступа: http://www.pushkin.edu.ru/.

Маремишова И. Русские сказки [Электронный ресурс] / И. Маремишова. - Режим доступа: http://www.rustrana.ru/.

Народные русские сказки 1992 - Народные русские сказки / под ред. А. Н. Афанасьева. - Алма-Ата : Шарапат, 1992. - 800 с.

Пропп 1928 - Пропп В. Я. Морфологические сказки / Владимир Яковлевич Пропп. - Л. : Академия, 1928. - 154 с.

Рошияну 1974 - Рошияну Н. Традиционные формулы сказки / Николае Рошияну. М. : Наука, 1974. - 216 c. 
Тверской губернатор приглашает в пещеру Кощея Бессмертного [Электронный pecypc]. - Режим доступа: http://www.tour-info.ru/.

Чай Кен Нам http://www. ruslang.ru/. - Чай Кен Нам. Языковое выражение культурных символов в русской народной сказке (на фоне корейского фольклора) : автореф. дис. ... канд. филол. наук : 10.02 .01 - русский язык [Электронный pecypc] / Чай Кен Нам. - Режим доступа: http://www. ruslang.ru/. 